\title{
Generation of Neuronal Diversity: Analogies and Homologies with Hematopoiesis
}

\author{
H. Nawa, ${ }^{*}$ T. Yamamori, T. Le, $\dagger$ and P.H. Patterson \\ Biology Division, California Institute of Technology, Pasadena, California 91125
}

\begin{abstract}
The immense variety of neuronal phenotypes in the vertebrate nervous system is apparent in considering just the process of chemical transmission. There are approximately 12 known classical neurotransmitters and more than 30 neuropeptides thus far identified, and individual neurons simultaneously synthesize, store, and secrete one or more classical transmitters in addition to three or more neuropeptides. The transmitters and peptides are expressed in an exceedingly large number of different combinations in different parts of the nervous system. Although there are useful generalizations as to the frequency of certain transmitterpeptide combinations, there are innumerable exceptions to these rules. How the particular combinations produced in each neuron are specified during development is a challenging question. The magnitude of this problem becomes clear if one calculates the number of possible combinations if a neuron is to produce 2 transmitters out of a possible 12 and 3 peptides out of a possible 30 . There are 267,960 different potential phenotypes in this example.
\end{abstract}

It has become increasingly clear that such phenotypic decisions are not made solely on the basis of a cell's lineage history. Clonal analysis in both the central and peripheral vertebrate nervous systems in situ has demonstrated that multipotential precursor cells can, right up to their final division, give rise to a variety of neurons and, in some cases, glia (Turner and Cepko 1987; Holt et al. 1988; Price and Thurlow 1988; Wetts and Fraser 1988; Bronner-Fraser and Fraser 1989; Galileo et al. 1990). This suggests that the precursor cells (and their immediate daughter cells) are not committed to a single fate (see also Tomlinson 1988; Anderson 1989). That postmitotic neurons can be influenced in their phenotypic choices by environmental signals has been convincingly shown for cells of both peripheral and central origin in vitro (see, e.g. , Patterson 1978; Kessler et al. 1984; Iacovitti et al. 1989; Adler and Hatlee 1989; Schoenen et al. 1989). Moreover, a variety of manipulations of cell position in vivo have indicated that the identity of a neuron's target can influence transmitter and peptide choices (McMahon and Gibson 1987; Schotzinger and Landis 1988; Wall and Taghert 1989). Many of these choices are revers-

\footnotetext{
Present addresses: "Institute of Immunology. Kyoto University. Kyoto, Japan; tUniversity of California Medical School. San Francisco, California 94143.
}

ible, and changes in transmitter and peptide phenotype can be part of normal development in situ, as growing neurons encounter new environments, in both vertebrate and invertebrate systems (Hayashi et al. 1983; Landis and Keefe 1983; Gesser and Larsson 1985; Happola et al. 1986; Koizumi and Bode 1986; Tublitz and Sylwester 1990).

What are the intercellular signals that control these phenotypic decisions? Using primary neuronal cultures as assay systems, it has been possible to identify a number of these signals and to characterize their biological activities and their biochemical properties (Fukada 1985; Wong and Kessler 1987; Adler et al. 1989; Lin et al. 1989; McManaman et al. 1989; Saadat et al. 1989; Stockli et al. 1989; Yamamori et al. 1989; Rao et al. 1990a). An early generalization that is arising from this work is that although these neuronal differentiation factors have distinct effects on a target neuron population, their effects can be partially overlapping or redundant. For instance, several factors with discrete biochemical properties can induce acetylcholine ( $\mathrm{ACh}$ ) production in cultured striatal and sympathetic neurons, but their effects on the expression of other transmitters and neuropeptides are distinct (Kessler 1986; Nawa and Patterson 1990). This emerging picture has a striking parallel in the control of phenotypic decisions in the hematopoietic system. Here too, biochemically diverse proteins produce distinct differentiation responses, but their effects can be partially overlapping (Metcalf 1989). Thus, although four hematopoietic regulators, with no sequence identity, elicit different arrays of derivatives from multipotential stem cell precursors, all four promote granulocyte and/or macrophage differentiation. In fact, this analogy between the nervous and hematopoietic systems has recently been carried a step further with the demonstration that the same protein can influence differentiation in both systems (Yamamori et al. 1989).

In this paper, we further examine the effects of this recombinant protein, known as leukemia inhibitory factor (LIF) and cholinergic differentiation factor (CDF), on cultured neurons. We present the dosedependence of its effects on the expression of various transmitters and neuropeptides in sympathetic neurons, and we show that it can act on another type of neuron eliciting somewhat different effects. The developmental profile of the onset of neuropeptide induction is also presented, and the reversibility of these 
effects is described. The conclusions are that CDF/LIF can act on several different types of neurons, that the response in each neuron is probably influenced by its lineage history, and that the factor must be continually present to maintain its effects on neuropeptide gene expression.

\section{METHODS}

Cell cultures. Sympathetic neuron cultures were prepared from neonatal rat superior cervical ganglia (SCG) using enzymatic dissociation and growth in L15$\mathrm{CO}_{2}$ medium plus $5 \%$ rat serum and nerve growth factor (NGF), according to the methods of Hawrot and Patterson (1979). Sensory neuron cultures were also prepared from dorsal root ganglia (DRG) of neonatal rats in the same way and grown in F-12 medium containing the $\mathrm{N} 2$ medium nutrient supplement and NGF (Lindsay 1988), Serum-free, heart-cell-conditioned medium $(\mathrm{CM})$ was prepared according to the method of Fukada (1980).

Transmitter and neuropeptide assays. After 14-16 days in culture, the intact sympathetic and sensory neurons were assayed for $\mathrm{ACh}$ and catecholamine (CA) synthesis from radioactive precursors, according to the methods of Mains and Patterson (1973). Sister neuronal cultures containing 1-6000 neurons were also extracted, and their neuropeptide contents were assayed by radioimmunoassay, according to the methods of Nawa and Sah (1990). The authenticity of these peptides was previously determined by high-performance liquid chromatography (Nawa and Sah 1990). The data are expressed as fmoles transmitter or peptide per 1000 neurons assayed.

Materials. Recombinant mouse and human CDF/ LIF produced by Escherichia coli (Gearing et al. 1989) was the kind gift from Dr. D. Metcalf and associates at the Walter and Eliza Hall Institute in Melbourne. NGF was produced by J. Carnahan. All other materials were produced according to the methods of Hawrot and Patterson (1979) and Nawa and Patterson (1990).

\section{RESULTS}

\section{Induction of Neuropeptides by Recombinant CDF/LIF}

It was shown previously that heart cell CM can induce the synthesis of several neuropeptides and their mRNAs, as well as $\mathrm{ACh}$ in cultured sympathetic neurons (Nawa and Sah 1990). Moreover, these neurons can respond to recombinant $\mathrm{CDF} / \mathrm{LIF}$ by the induction of $\mathrm{ACh}$ synthesis and the reduction of $\mathrm{CA}$ synthesis (Yamamori et al. 1989). Therefore, we sought to determine whether the peptide inductions by $\mathrm{CM}$ were also due to CDF/LIF (see also Nawa and Patterson 1990). Using recombinant CDF/LIF, we find that this protein does increase neuronal substance $P(S P)$ and somatostatin (SOM), whereas it reduces neuropeptide

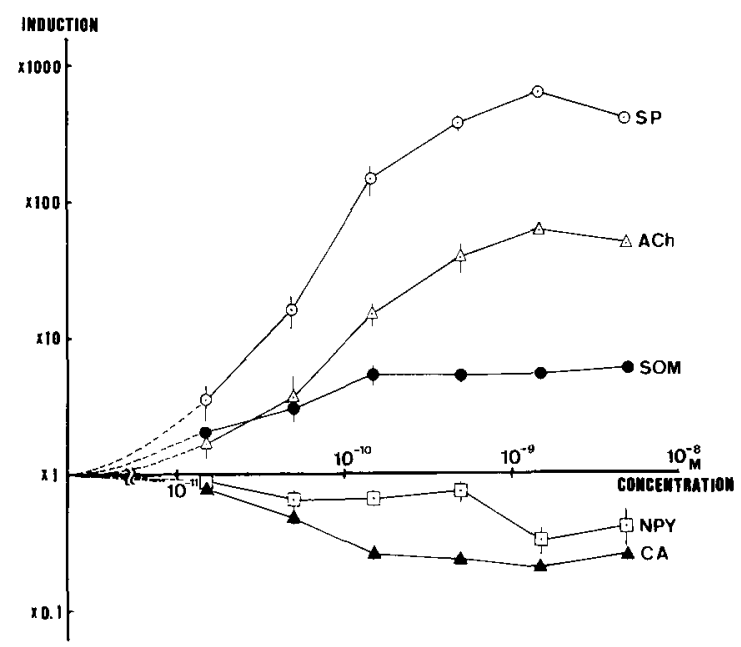

Figure 1. Dose dependence of recombinant CDF/LIF effects on neurotransmitter and neuropeptide choice. Recombinant mouse CDF/LIF was added at various concentrations (abcissa) to cultured sympathetic neurons for 12 days. Transmitter synthesis and peptide content were measured as described in Methods. The values are normalized to neuron number by counting neurons, and the data are calculated as the mean \pm S.E.M. The ratio to the control (no CDF/LIF) value is shown on the ordinate. The control values were $\mathrm{SP}=0.07 \pm 0.03$, $\mathrm{SOM}=34.0 \pm 2.0$, and $\mathrm{NPY}=1100.0 \pm 200.0$ fmoles $/ 1000$ neurons. and $\mathrm{ACh}=170.0 \pm 2.0$, and $\mathrm{CA}=3600.0 \pm 500.0$ fmoles/ 1000 neurons/hour. The cultures contained the following numbers of neurons: control $=8448 \pm 1260,17 \mathrm{pM}=$ $6971 \pm 774.50 \mathrm{pM}=6507 \pm 788,170 \mathrm{pM}=5016 \pm 1027,500$ $\mathrm{pM}=2760 \pm 270,1.7 \mathrm{nM}=1582 \pm 224,5 \mathrm{nM}=1020 \pm 39$. The lower number of surviving neurons at the higher CDF/LIF concentrations is not yet explained. Since such an effect was not observed for purified CDF (Fukada 1985; Nawa and Patterson 1990), it is possible that the recombinant preparation contains a toxic contaminant. It is clear, however, that differential survival of various populations of predetermined neurons is not the explanation for the effects on transmitter/ peptide phenotype (Patterson 1978; Potter et al. 1986; Nawa and Sah 1990).

$\mathrm{Y}$ (NPY) (Fig, 1). The inductions of ACh, SP, and SOM were observed at CDF/LIF concentrations well below $0.1 \mathrm{nM}$, with approximately $2 \mathrm{nM}$ required for maximal induction of $\mathrm{SP}$ and $\mathrm{ACh}$. The reductions in CA and NPY were less marked but required protein concentrations similar to those for the positive inductions. These effects are all consistent with previous results obtained using the protein purified from CM. The NPY suppression was not obvious when crude heart cell CM was added to the neurons (Nawa and Sah 1990; see also Marek and Mains 1989). The lack of effect with CM could be due to a lower concentration of CDF/LIF in the medium than was added with the recombinant protein or to the presence of a factor in the medium that acted to counter the effect of $\mathrm{CDF} /$ LIF.

\section{Time Course of Peptide Induction and Its Reversibility}

The induction of ACh synthesis in cultured sympathetic neurons by heart cell $\mathrm{CM}$ is slow, requiring 
several weeks for the major increase to occur (Patterson and Chun 1977; see also Johnson et al. 1976). Given that the same protein can induce the production of several neuropeptides, it was of interest to determine whether the peptide changes followed a time course similar to that of $\mathrm{ACh}$. When sympathetic neurons are grown in a $100 \%$ volume equivalent of heart cell $\mathrm{CM}$, the developmental profiles of SP and SOM induction (Fig. 2) are both very similar to that observed previously for ACh. The major induction of vasoactive intestinal polypeptide (VIP), however, is considerably slower, with the major increase occurring after 12 days and still rising at 24 days. Thus, there appear to be two phases in the VIP induction, the second of which does not correspond in time to those of $\mathrm{ACh}, \mathrm{SP}$, and SOM.

These changes in phenotype in postmitotic neurons raise the question of reversibility and age dependence. The culture paradigm offers an excellent opportunity to ask whether the neuropeptide changes induced by CM are reversible. When $C M$ was withdrawn from the sympathetic neurons on day 12 , a dramatic decline in SP, SOM, and VIP levels was observed (Fig. 2). The apparent rise in VIP seen at day 24 in the absence of $\mathrm{CM}$ is unexplained at present. Overall then, not only the induction of these peptides, but their maintenance appears to be completely dependent on the continued presence of $\mathrm{CM}$.

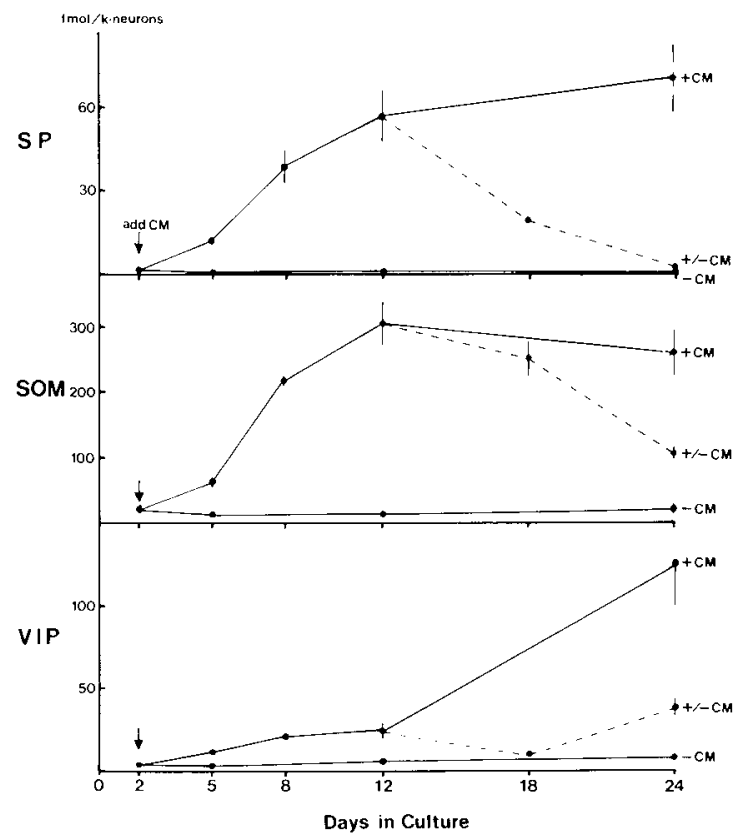

Figure 2. Time course of neuropeptide induction and its reversibility. Sympathetic neurons were grown in $100 \%$ volume equivalent of heart cell $\mathrm{CM}$ from day 2 . On days $5,8,12$, and 24. total peptides were extracted from three sister cultures. and radioimmunoassays were carried out for SP, SOM, and VIP (solid lines). On day 12. CM was withdrawn from some of the CM cultures to assess the reversibility of its effects (dashed lines). The culture medium was changed every 2 days, and 10 $\mu \mathrm{m}$ cytosine arabinoside was added on days $(0,2,5,10$, and 16 to suppress nonneuronal cell proliferation. Neuronal numbers did not differ significantly among the various groups of cultures.

\section{Neuronal Specificity of CDF/LIF}

The dramatic changes in gene expression elicited in sympathetic neurons by CDF/LIF raises the question as to whether this factor is specific for these neurons or whether it can act in a widespread fashion in the nervous system. If it can act on other neurons, does it induce the same set of transmitters and peptides that it does in sympathetic neurons? Since a similar cholinergic factor from skeletal muscle can induce $\mathrm{ACh}$ synthesis in cultured sensory neurons from nodose ganglia (Mathieu et al. 1984), we tested recombinant CDF/ LIF on sensory neurons, in this case from DRG. The results of such an experiment are given in Table 1 . The most significant changes induced by $\mathrm{CDF} / \mathrm{LIF}$ in the DRG neurons are 13-fold increases in ACh synthesis and VIP content. There is also a small reduction in SP. Therefore, CDF/LIF does alter the phenotype of sensory neurons, and it induces several of the same changes that it does in sympathetic neurons, namely, $\mathrm{ACh}$ and VIP induction. The effects on the DRG neurons are, however, not identical to those with sympathetic neurons, since SP and SOM are not increased in the sensory neurons. A reduction in $\mathrm{CA}$ synthesis is also not apparent, but the control levels of CA synthesis are too low to be sure if a CA suppression effect could be seen. Similarly, the large errors in the NPY measurements mitigated against drawing firm conclusions about a lowering of the level of this peptide. These results support the idea that a neuron's lineage history can influence its particular response to a given differentiation factor.

\section{DISCUSSION}

\section{Hematopoietic Analogy}

There are several parallels in the generation of cell diversity in the neural crest lineage and in the hematopoietic system: Both systems appear to arise from multipotent stem cells that give rise to progenitor cells committed to particular sublineages, and in both systems, extracellular signals can influence which differentiation pathways are taken (Anderson 1989). It is the last point concerning phenotypic instructive factors to which the present work relates. It was previously shown that the CDF from heart cells can alter neuropeptide as well as neurotransmitter expression in cultured sympathetic neurons (Nawa and Patterson 1990), and we here demonstrate that recombinant CDF/LIF duplicates these various activities (see also Yamamori et al. 1989). That this protein also influences the proliferation and differentiation of a myeloid cell line (Gearing et al. 1987) draws the two systems together at the molecular level as well. It should be noted, however, that it is not yet known how or when LIF acts in the hematopoietic lineage (Metcalf and Gearing 1989). Recent evidence implicates CDF / LIF in the control of cell proliferation and differentiation in many different tissues, from the earliest embryo through adulthood (Gough and Williams 1989). These findings suggest 
Table 1. Effect of CDF/LIF on Neurotransmitter and Neuropeptide Choices in Sympathetic and Sensory Neurons

\begin{tabular}{|c|c|c|c|c|c|c|c|}
\hline Neuron & $\mathrm{CDF} / \mathrm{LIF}$ & $\mathrm{ACh}$ & $\mathrm{CA}$ & SP & $\mathrm{SOM}$ & VIP & NPY \\
\hline \multirow[t]{2}{*}{$\overline{\mathrm{SCG}}$} & + & $4400 \pm 400$ & $730 \pm 180$ & $59 \pm 6.0$ & $48 \pm 5$ & $9.7 \pm 0.6$ & \\
\hline & - & $330 \pm 50$ & $3200 \pm 300$ & $0.4 \pm 0.0$ & $4 \pm 2$ & $1.1 \pm 0.4$ & \\
\hline \multirow[t]{2}{*}{ DRG } & + & $53 \pm 5$ & $0.4 \pm 0.2$ & $2.1 \pm 0.2$ & $2.5 \pm 1.3$ & $2.7 \pm 0.4$ & $66 \pm 28$ \\
\hline & - & $4 \pm 4$ & $0.6 \pm 0.4$ & $5.0 \pm 0.9$ & $3.5 \pm 1.6$ & $0.2 \pm 0.2$ & $75 \pm 21$ \\
\hline
\end{tabular}

Sympathetic neurons from the SCG were cultured in serum-containing medium with or without $1 \mathrm{~nm}$ recombinant human CDF/LIF for 12 days. Sensory neurons from the DRG were grown in defined medium as described in Methods. To suppress nonneuronal cell growth, $10 \mu \mathrm{M}$ cytosine arabinoside was added during the first 7 days (SCG) or between 24 and 48 hours (DRG). The number of neurons did not differ significantly between the various groups of cultures, and nonneuronal cells were not observed in the SCG cultures. Some nonneuronal cells were observed in the DRG cultures, numbering $<10 \%$ of the total cell population. Transmitters and peptides were assayed as described in Methods. ACh and CA values are expressed as fmoles/1000 neurons/hour, and the peptides are expressed as fmoles/1000 neurons.

that it may be rewarding to study the effects of other cytokines and hematopoietic regulators on neuronal phenotypic choices, as well as to investigate whether neuronal factors can influence hematopoietic decisions.

\section{Role of CDF/LIF In Situ}

To understand the role of CDF/LIF in neuronal development in the intact organism, it will be necessary to localize the factor in situ, describe which cells have receptors for it, and to perform appropriate perturbation experiments. Although such data are not yet available, one can ask if the effects of CDF/LIF on cultured neurons mimic any of the phenotypes known from descriptive studies of normal neurons. The present experiments and those of Nawa and Patterson (1990) show that CDF/LIF can each induce the expression of ACh and VIP while causing a corresponding reduction in CA and NPY. The striking aspect of these results is that these are precisely the pairs of transmitters and peptides that are generally colocalized together in cholinergic (ACh + VIP) and noradrenergic (CA + NPY) peripheral neurons; these pairings have been termed one of the organizational principles of the sympathetic nervous system (Lundberg et al. 1982). Thus, we would expect that the natural neuronal differentiation signal operating in the sweat glands of the rat foot pad, for instance, where the noradrenergic-to-cholinergic switch in phenotype is observed during normal development (Landis and Keefe 1983), would regulate these pairs of transmitters and peptides coordinately, as does CDF/LIF. The simplest picture would then involve a unique neuronal differentiation signal for each distinct combination of transmitters and peptides.

There are, however, a great many exceptions to the general rules of transmitter/peptide pairings. NPY is sometimes found in cholinergic neurons, for instance, and VIP in noncholinergic neurons (cf. Leblanc and Landis 1988). To take these exceptions into account, simple models might include separate differentiation factors for each transmitter and peptide or factors that both suppress and induce single or combinations of transmitters and peptides. Although it is clearly too early to draw firm conclusions, the data that are available support both alternatives. That is, some purified neuronal differentiation factors, such as CDF/LIF, ciliary neurotrophic factor, and membrane-associated neurotransmitter stimulating factor, can each induce the expression of several transmitters and peptides as well as suppress others (Wong and Kessler 1987; Ernsberger et al. 1989; Nawa and Patterson 1990; Rao et al. 1990a), whereas several newly described factors appear to have more narrow effects on neuronal gene expression (Nawa and Patterson 1990).

In the particular case of the sympathetic innervation of the sweat gland in the rat, a combination of factors may be required to explain the observed transmitter/ peptide phenotype. These axons switch from a CA phenotype to an ACh-VIP-CGRP (calcitonin-generelated peptide) phenotype on arrival at this target (Landis et al. 1988; Schotzinger and Landis 1988). It is particularly noteworthy that SP has not been detected in these neurons because all three cholinergic factors known to act on cultured sympathetic neurons do induce SP (Wong and Kessler 1987; Nawa and Sah 1990; Rao et al. 1990b and unpubl.). Three hypotheses that can reconcile these results are as follows: (1) In none of these proteins is the factor acting normally in the sweat gland, (2) the sympathetic neurons do not show an SP response to CDF (for instance) in vivo, and (3) the SP part of the response to CDF (for example) is counterbalanced by another factor in the sweat gland that acts to suppress SP expression. In this regard, it is interesting that soluble extracts of rat foot pads (including sweat glands) contain a factor(s) that mimics the action of the known cholinergic factors on cultured sympathetic neurons, including the induction of SP (Rao et al. $1990 \mathrm{~b}$ and unpubl.)

\section{Neuronal Targets for CDF/LIF}

Another aspect of the role of CDF/LIF concerns how many types of neurons respond to it. That is, does the protein act only on the sympathetic neurons that were used as the assay for its purification, or can it act on other neurons that are normally cholinergic? Can it 
induce cholinergic properties in neurons that do not normally display such a phenotype? The investigations of Weber et al. (1985) demonstrated that skeletal muscle $\mathrm{CM}$ contains a cholinergic neuronal differentiation factor that very closely resembles CDF/LIF. The skeletal muscle protein can enhance cholinergic differentiation in cultures of partially purified rat motor neurons and nodose ganglion sensory neurons without altering neuronal survival (Mathieu et al. 1984; Martinou et al. 1989). These findings suggest a potentially widespread role for this factor. We assayed recombinant CDF/LIF on another population of neurons, DRG sensory neurons, that are not known to produce ACh normally in situ. CDF/LIF does enhance ACh synthesis in these neurons, as well as VIP expression. Quantitatively, the observed increases are not as great as those seen with sympathetic neurons, but we have not yet attempted to optimize this effect by testing higher concentrations of factor or by testing DRG neurons from different developmental stages.

What does the apparently widespread distribution of putative receptors for CDF/LIF mean for its biological role? One possibility is that normally, in vivo, most neurons are not responsive to this factor. That is, the response observed here represents a derepression of the receptor in culture (or some other aspect of the response pathway); normally, expression of the $\mathrm{CDF} /$ LIF receptor is closely regulated and restricted in developmental time and location. It is also possible that many neurons do have the capacity to respond to this factor in situ but that expression of CDF/LIF itself is closely regulated and restricted in developmental time and location. Yet another possibility is that many neurons do express the CDF/LIF receptor and do encounter the factor in situ, but they are prevented from responding to it by another factor in their environment. Such factors might include glial cells (Spiegel et al. 1990) and neuronal activity (Walicke et al. 1977), both of which have been shown to inhibit the response of cultured sympathetic neurons to cholinergic or peptidergic factors.

\section{Reversibility of the CDF/LIF Effects}

How permanent are the effects of CDF/LIF? Put another way, if the early decision to become catecholaminergic is reversible, is the subsequent decision to become cholinergic similarly plastic? Vidal et al. (1987) found that removal of skeletal muscle CM from sympathetic neurons at later times in culture resulted in a leveling off of the rise in choline acetyltransferase activity and a concomitant induction of tyrosine hydroxylase activity. Reversibility in cholinergic development was observed by Patterson and Chun (1977), but they found that such changes became quantitatively less with neuronal age in culture. Similarly, although mature sympathetic neurons taken from adult rats can become cholinergic when exposed to the appropriate environment in culture, they do so at a lower frequency or with a slower time course (Wakshull et al. 1979; Johnson et al. 1980; Potter et al. 1986; see also Lindsay et al. 1989). In an entirely in vivo paradigm, Coulombe and Bronner-Fraser (1986) showed that cholinergic, parasympathetic neurons could store catecholamines when transplanted to the appropriate environment.

The present experiments extend the reversibility phenomenon to neuropeptide expression. These findings, taken with those reviewed above (and McMahon and Gibson 1987), imply that the transmitter and peptide phenotypes observed in mature neurons in the adult organism are being actively maintained by the appropriate differentiation factors. This idea is consistent with the adult vertebrate nervous system being in a state of dynamic equilibrium. In this view, rather than being static or fixed, maturity actually represents a balance between regression of processes and connections, and sprouting of new processes and the formation of novel connections (Patterson and Purves 1982; Purves and Lichtman 1985). It may be that this continual remodeling of the system could also involve the chemical identity of the neurons, an extreme form of synaptic plasticity.

\section{ACKNOWLEDGMENTS}

We are grateful to Dr. Donald Metcalf and colleagues of the Walter and Eliza Hall Institute for Medical Research in Melbourne for recombinant LIF. We thank D. McDowell for help with the preparation of tissue culture materials and J. Carnahan for preparation of NGF. This work was supported by the National Institute of Neurological Disorders and Stroke (Javits Neuroscience Investigator Award) and a McKnight Foundation Neuroscience Research Project Award (P.H.P.); by the Muscular Dystrophy Association, the Del Webb Foundation and the Japanese Ministry of Education, Science, and Culture (H.N.); by a Caltech Summer Undergraduate Research Fellowship (T.L.); and by the Alzheimer's Disease and Related Disorders Association (T.Y.).

\section{REFERENCES}

Adler, R. and M. Hatlee. 1989. Plasticity and differentiation of embryonic retinal cells after terminal mitosis. Science 243: 391 .

Adler, J.E., L.S. Schleifer, and L.B. Black. 1989. Partial purification and characterization of a membrane-derived factor regulating neurotransmitter phenotypic expression. Proc. Natl. Acad. Sci. 86: 1080.

Anderson, D.J. 1989. The neural crest cell lineage problem: Neuropoiesis? Neuron 3: 1.

Bronner-Fraser, M. and S. Fraser. 1989. Developmental potential of avian trunk neural crest cells in situ. Neuron 3: 755 .

Coulombe, J.N. and M. Bronner-Fraser. 1986. Cholinergic neurones acquire adrenergic neurotransmitters when transplanted into an embryo. Nature 324: 569.

Ernsberger, U., M. Sendtner, and H. Rohrer. 1989. Proliferation and differentiation of embryonic chick sympathetic neurons: Effects of ciliary neurotrophic factor. Neuron 2: 1275 . 
Fukada, K. 1980. Hormonal control of neurotransmitter choice in sympathetic neuron cultures. Nature 287: 553 . 1985. Purification and partial characterization of a cholinergic differentiation factor. Proc. Nall. Acad. Sci. 82: 8795 .

Galileo, D.S.. G.E. Gray, G.C. Owens, J. Majors, and J.R. Sanes. 1990 . Neurons and glia arise from a common progenitor in chicken optic tectum: Demonstration with two retroviruses and cell type-specific antibodies. Proc. Natl. Acad. Sci. 87: 458.

Gearing, D.P., N.A. Nicola, D. Metcalf, S. Foote, T.A. Willson, N.M. Gough, and R.L. Williams. 1989. Production of leukemia inhibitory factor (LIF) in Escherichia coli by a novel procedure and its use in maintaining embryonic stem (EC) cells in culture. Biotechnology 7: 1157.

Gearing, D.P., N.M. Gough, J.A. King, D.J. Hilton, N.A. Nicola, R.J. Simpson, E.C. Nice, A. Kelso, and D. Metcalf. 1987. Molecular cloning and expression of cDNA encoding a murine myeloid leukaemia inhibitory factor (LIF). EMBO J. 6: 3395 .

Gesser, B.P. and L.I. Larsson. 1985. Changes from enkephalin-like to gastrin/cholecystokinin-like immunoreactivity in snail neurons. $J$. Neurosci. 5: 1412.

Gough, N.M. and R.L. Williams. 1989. The pleiotropic actions of leukemia inhibitory factor. Cancer Cells 1: 77.

Happola, O., H. Paivarinta, S. Soinila, and H. Steinbusch. 1986. Pre- and postnatal development of 5-hydroxytryptamine-immunoreactive cells in the superior cervical ganglion of the rat. J. Auton. Nerv. Syst. 15: 21.

Hawrot, E. and P.H. Patterson. 1979. Long-term culture of dissociated sympathetic neurons. Methods Enzymol. 53: 574 .

Hayashi, M., D. Edgar, and H. Thoenen. 1983. The development of substance $P$, somatostatin and vasoactive intestinal polypeptide in sympathetic and spinal setwory ganglia of the chick embryo. Neurascience 10: 31 .

Holt, C.E., T.W. Bertsch, H.M. Ellis, and W.A. Harris. 1988. Cellular determination in the Xenopus retina is independent of lineage and birth date. Neuron 1: 15 .

Iacovitti, L., M.J. Evinger, T.H. Joh, and D.J. Reis. 1989. A muscle-derived factor(s) induces expression of a catecholamine phenotype neurons in neurons of cultured rat cerebral cortex. J. Neurosci. 9: 3529.

Johnson, M., C.D. Ross, and R.P. Bunge. 1980. Morphological and biochemical studies on the development of cholinergic properties in cultured sympathetic neurons. II. Dependence on postnatal age. J. Cell Biol. 84: 692 .

Johnson, M., D. Ross, M. Meyers, R. Rees, R. Bunge, E Wakshull, and H. Burton. 1976. Synaptic vesicle cytochemistry changes when cultured sympathetic neurones develop cholinergic interactions. Nature 262: 308.

Kessler, J.A. 1986. Differential regulation of cholinergic and peptidergic development in the rat striatum in culture. Dev. Biol. 113: 77

Kessler, J.A., J.E. Adler, G.M. Jonakait, and I.B. Black. 1984. Target organ regulation of substance $P$ in sympathetic neurons in culture. Dev. Biol. 103: 71.

Koizumi, O. and H.R. Bode. 1986. Plasticity in the nervous system of adult hydra. I. The position-dependent expression of MRFamide-like immunoreactivity. Dev. Biol. 116: 407

Landis, S.C. and D. Keefe. 1983. Evidence for neurotransmitter plasticity in vivo: Developmental changes in the properties of cholinergic sympathetic neurons. Dev. Biol. 98: 349 .

Landis, S.C., M. Schwab, and R.E. Siegel. 1988. Evidence for neurotransmitter plasticity in vivo. II. Immunocytochemical studies of rat sweat gland innervation. Dev. Biol. 126: 129

Leblanc, G. and S.C. Landis. 1988. Target specificity of neuropeptide Y-immunoreactive cranial parasympathetic neurons. J. Neurosci. 8: 146.

Lindsay, R. 1988. Nerve growth factors (NGF, BDNF) en- hance axonal regeneration but are not required for survival of adult sensory neurons. J. Neurosci. 8: 2394.

Lindsay, R., C. Lockett, J. Sternberg, and J. Winter. 1989 Neuropeptide expression in cultures of adult sensory neurons - Modulation of substance- $\mathrm{P}$ and calcitonin gene-related peptide levels by nerve growth-factor. Neuroscience 33: 53 .

Lin, L.-F.H., D. Mismer, J.D. Lile, L.G. Armes, E.T. Butler, J.L. Vannice, and F. Collins. 1989. Purification, cloning and expression of ciliary neurotrophic factor (CNTF). Science 246: 1023 .

Lundberg, J.M., T. Hokfelt, A. Anggard, L. Terenius, R. Elde, K. Markey, M. Goldstein, and J. Kimmel. 1982. Organizational principles in the peripheral sympathetic nervous system: Subdivision by coexisting peptides (somatostatin-, avian pancreatic polypeptide-, and vasoactive intestinal polypeptide-like immunoreactive materials). Proc. Natl. Acad. Sci. 79: 1303.

Mains, R.E. and P.H. Patterson. 1973. Primary cultures of dissociated sympathetic neurons. I. Establishment of longterm growth in culture and studies of differentiated properties. J. Cell Biol. 59: 329.

Marek, K.L. and R.E. Mains. 1989. Biosynthesis, development and regulation of neuropeptide $\mathrm{Y}$ in superior cervical ganglion culture. J. Neurochem. 52: 1807.

Martinou, J.C., A.L.V. Thai, G. Cassar, F. Roubinet, and M.J. Weber. 1989. Characterization of two factors enhancing choline acetyltransferase activity in cultures of purified rat motoneurons. J. Neurosci. 9: 3645 .

Mathieu. C., A. Moisand, and M.J. Weber. 1984. Acetylcholine metabolism by cultured neurons from rat nodose ganglia: Regulation by a macromolecule from muscleconditioned medium. Neuroscience 13: 1373.

McMahon, S.B. and S. Gibson. 1987. Peptide expression is altered when afferent nerves reinnervate inappropriate tissue. Neurosci. Lett. 73: 9.

McManaman, J., F. Crawford, R. Clark, J. Richker, and F. Fuller. 1989. Multiple factors from skeletal muscle: Demonstration of effects of basic neurotrophic fibroblast growth factor and comparisons with the 22-kilodalton choline acetyltransferase development factor. J. Neurochem. 53: 1763 .

Metcalf, D. 1989. The molecular control of cell division, differentiation commitment and maturation in haemopoietic cells. Nature 339: 27

Metcalf, D. and D.P. Gearing. 1989. Fatal syndrome in mice engrafted with cells producing high levels of the leukemia inhibitory factor. Proc. Natl. Acad. Sci. 86: 5948.

Nawa, H. and P.H. Patterson. 1990. Separation and partial characterization of neuropeptide-inducing factors in heart cell conditioned medium. Neuron 4: 269.

Nawa, H. and D.W.Y. Sah. 1990. Different biological activities in conditioned media control the expression of a variety of neuropeptides in cultured sympathetic neurons. Neuron 4: 279 .

Patterson, P.H. 1978. Environmental determination of autonomic neurotransmitter functions. Annu. Rev. Neurosci. 1: 1 .

Patterson, P.H. and L.L.Y. Chun. 1977. The induction of acetylcholine synthesis in primary cultures of dissociated rat sympathetic neurons. 11. Developmental aspects. Dev. Biol. 60: 473 .

Patterson, P.H. and D. Purves. 1982. Readings in developmental neurobiology. Cold Spring Harbor Laboratory, Cold Spring Harbor, New York.

Potter, D.D., S.C. Landis, S.G. Matsumoto, and E.J. Furshpan. 1986. Synaptic functions in rat sympathetic neurons in microcultures. II. Adrenergic/cholinergic dual status and plasticity. J. Neurosci. 6: 1080 .

Price, J. and L. Thurlow. 1988. Cell lineage in the rat cerebral cortex. A study using retroviral-mediated gene-transfer. Development 104: 473.

Purves, D. and J.W. Lichtman. 1985. Principles of neural 
development. Sinauer Associates, Sunderland, Massachusetts.

Rao, M.S., S.C. Landis, and P.H. Patterson. 1990a. The cholinergic neuronal differentiation factor from heart cell conditioned medium is different from the cholinergic factors in sciatic nerve and spinal cord. Dev. Biol. 139: 65 .

Rao, M.S., P.H. Patterson, and S.C. Landis. $1990 \mathrm{~b}$. Characterization of a target derived cholinergic differentiation factor present in rat sweat glands. Soc. Neurosci. Abstr. 16: (in press).

Saadat, S., M. Sendtner, and H. Rohrer. 1989. Ciliary neurotrophic factor induces cholinergic differentiation of rat sympathetic neurons in culture. J. Cell Biol. 108: 1807.

Schoenen, J., P. Delree, P. Leprince, and G. Moonen. 1989. Neurotransmitter phenotype plasticity in cultured dissociated adult rat dorsal root ganglia: An immunochemical study. J. Neurosci. Res. 22: 473.

Schotzinger, R.J. and S.C. Landis. 1988. Cholinergic phenotype developed by noradrenergic sympathetic neurons after innervation of a novel cholinergic target in vivo. Nature 335: 637.

Spiegel, K., V. Wong, and J.A. Kessler. 1990. Translational regulation of somatostatin in cultured sympathetic neurons. Neuron 4: 303.

Stockli, K.A., F. Lottspeich, M. Sendtner, P. Masiakowski, P. Caroll, R. Gotz, D. Lindholm, and H. Thoenen. 1989. Molecular cloning, expression and regional distribution of rat ciliary neurotrophic factor. Nature 342: 920.

Tomlinson, A. 1988. Cellular interactions in the developing Drosophila eye. Development 104: 183.

Tublitz, N.J. and A.W. Sylwester. 1990. Postembryonic alteration of transmitter phenotype in individually identified peptidergic neurons. J. Neurosci. 10: 161.
Turner, D. and C.L. Cepko. 1987. A common progenitor for neurons and glia persists in rat retina late in development. Nature 328: 131 .

Vidal, S., B. Raynaud, D. Clarous, and M.J. Weber. 1987. Neurotransmitter plasticity of cultured sympathetic neurones. Are the effects of muscle-conditioned medium reversible? Development 101: 617.

Wakshull, E., M.I. Johnson, and H. Burton. 1979. Postnatal rat sympathetic neurons in culture. II. Synaptic transmission by postnatal neurons. J. Neurophysiol. 42: 1426.

Walicke, P.A., R.B. Campenot, and P.H. Patterson. 1977. Determination of transmitter function by neuronal activity. Proc. Natl. Acad. Sci. 74:5767.

Wall, J.B. and P.H. Taghert. 1989. Regulation of neuropeptide phenotypes in identified neurons of Manduca embryos. Soc. Neurosci. Abstr. 15: 448.

Weber, M.J., B. Raynaud, and C. Delteil. 1985. Molecular properties of a cholinergic differentiation factor from muscle-conditioned medium. J. Neurochem. 45: 1541.

Wetts, R. and S.E. Fraser. 1988. Multipotent precursors can give rise to all major cell types of the frog retina. Science 239: 1142.

Wong, V. and J.A. Kessler. 1987. Solubilization of a membrane factor that stimulates levels of substance $P$ and choline acetyltransferase in sympathetic neurons. Proc. Natl. Acad. Sci. 84: 8726.

Yamamori, T., K. Fukada, R. Aebersold, S. Korsching, M.-J. Fann, and P.H. Patterson. 1989. The cholinergic neuronal differentiation factor from heart cells is identical to leukemia inhibitory factor. Science 246: 1412. 


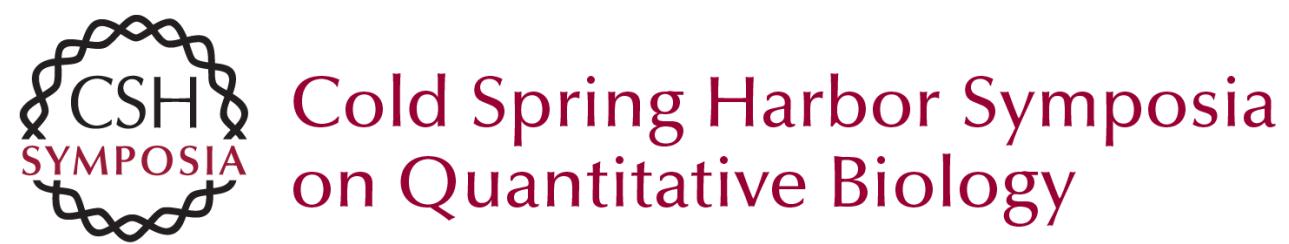

\section{Generation of Neuronal Diversity: Analogies and Homologies with Hematopoiesis}

H. Nawa, T. Yamamori, T. Le, et al.

Cold Spring Harb Symp Quant Biol 1990 55: 247-253

Access the most recent version at doi:10.1101/SQB.1990.055.01.027

References This article cites 61 articles, 24 of which can be accessed free at:

http://symposium.cshlp.org/content/55/247.refs.html

Article cited in:

http://symposium.cshlp.org/content/55/247\#related-urls

Email alerting

Receive free email alerts when new articles cite this article service sign up in the box at the top right corner of the article or click here

To subscribe to Cold Spring Harbor Symposia on Quantitative Biology go to: http://symposium.cshlp.org/subscriptions 